\title{
Relating GPI-Anchored Ly6 Proteins uPAR and CD59 to Viral Infection
}

\author{
Jingyou Yu 1,2,+(D), Vaibhav Murthy ${ }^{1,2}$ (D) and Shan-Lu Liu 1,2,3,4,*(D) \\ 1 Center for Retrovirus Research, The Ohio State University, Columbus, OH 43210, USA; \\ yu.2123@osu.edu (J.Y.); murthy.39@buckeyemail.osu.edu (V.M.) \\ 2 Department of Veterinary Biosciences, The Ohio State University, Columbus, OH 43210, USA \\ 3 Department of Microbial Infection and Immunity, The Ohio State University, Columbus, OH 43210, USA \\ 4 Viruses and Emerging Pathogens Program, Infectious Diseases Institute, The Ohio State University, \\ Columbus, $\mathrm{OH} 43210$, USA \\ * Correspondence: liu.6244@osu.edu; Tel.: +1-614-292-8690 \\ + Present address: Center for Virology and Vaccine Research, Beth Israel Deaconess Medical Center, Harvard \\ Medical School, Boston, MA 02115, USA.
}

Received: 17 October 2019; Accepted: 12 November 2019; Published: 14 November 2019

\begin{abstract}
The Ly6 (lymphocyte antigen-6)/uPAR (urokinase-type plasminogen activator receptor) superfamily protein is a group of molecules that share limited sequence homology but conserved three-fingered structures. Despite diverse cellular functions, such as in regulating host immunity, cell adhesion, and migration, the physiological roles of these factors in vivo remain poorly characterized. Notably, increasing research has focused on the interplays between Ly6/uPAR proteins and viral pathogens, the results of which have provided new insight into viral entry and virus-host interactions. While LY6E (lymphocyte antigen 6 family member E), one key member of the Ly6E/uPAR-family proteins, has been extensively studied, other members have not been well characterized. Here, we summarize current knowledge of Ly6/uPAR proteins related to viral infection, with a focus on uPAR and CD59. Our goal is to provide an up-to-date view of the Ly6/uPAR-family proteins and associated virus-host interaction and viral pathogenesis.
\end{abstract}

Keywords: Ly6/uPAR; viruses; Ly6E; uPAR/CD87; CD59

\section{Introduction: Biosynthesis, Structure, and Functions}

The Ly6 (lymphocyte antigen-6)/uPAR (urokinase-type plasminogen activator receptor) superfamily proteins were initially identified as $\mathrm{T}$ cell antigens in activated murine $\mathrm{T}$ lymphocytes by alloantisera staining [1,2]. The first molecular cloning of Ly6 cDNA was carried out in 1986, revealing a group of genes in the Ly6 gene in murine chromosomes 15 [3]. Since then, multiple genes in the Ly6 family have been isolated, including murine LY6A [4], LY6C [4], LY6E [5], LY6I [6], among others (Table 1). Human orthologs were isolated shortly after and most of these genes were mapped to human chromosome 8 [7] (Table 1). To date, Ly6/uPAR genes have been discovered in insects [8], fish [9], amphibians [10], reptiles [11], birds [12], and mammals [13] (Table 1). The general knowledge of the Ly6/uPAR family, including their genomic organization, tissue distribution, and evolution, has been elegantly reviewed elsewhere (refer to [7,14-16]). 
Table 1. Features of major Ly6/uPAR proteins.

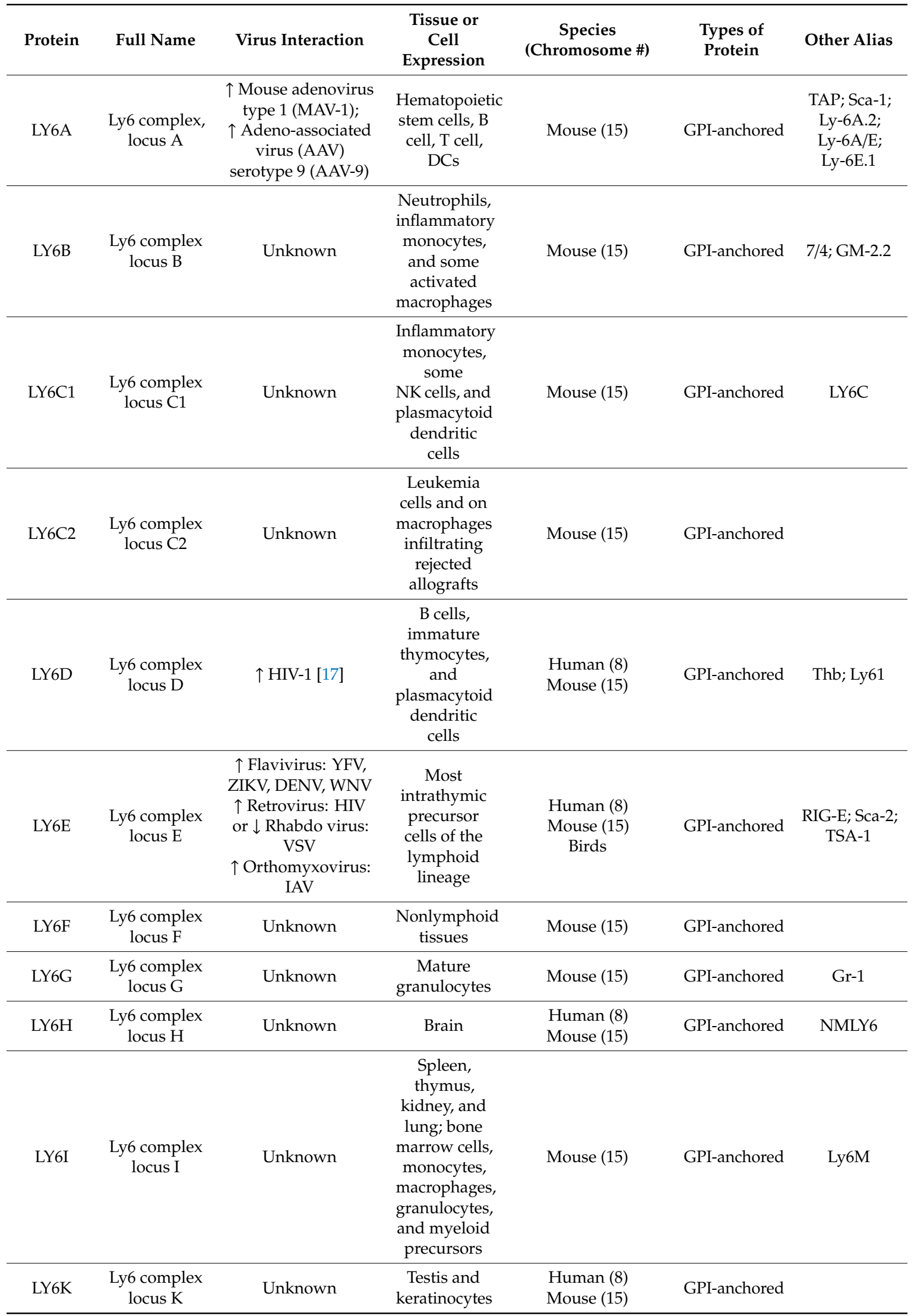


Table 1. Cont.

\begin{tabular}{|c|c|c|c|c|c|c|}
\hline Protein & Full Name & Virus Interaction & $\begin{array}{l}\text { Tissue or } \\
\text { Cell } \\
\text { Expression }\end{array}$ & $\begin{array}{c}\text { Species } \\
\text { (Chromosome \#) }\end{array}$ & $\begin{array}{l}\text { Types of } \\
\text { Protein }\end{array}$ & Other Alias \\
\hline LYPD2 & $\begin{array}{l}\text { Ly6/Plaur } \\
\text { domain-containing } \\
2\end{array}$ & g Unknown & $\begin{array}{l}\text { Esophagus, } \\
\text { skin, and } \\
\text { stomach }\end{array}$ & $\begin{array}{l}\text { Human (8) } \\
\text { Mouse (15) }\end{array}$ & GPI-anchored & VLL; Lypdc2 \\
\hline SLURP1 & $\begin{array}{c}\text { Secreted } \\
\text { Ly6/Plaur } \\
\text { domain-containing } \\
1\end{array}$ & g Unknown & $\begin{array}{l}\text { Restricted in } \\
\text { esophagus }\end{array}$ & $\begin{array}{l}\text { Human (8) } \\
\text { Mouse (15) }\end{array}$ & Secreted & ARS \\
\hline LYNX1 & Ly6/neurotoxin & Unknown & Unknown & Human (8) & Secreted & SLURP2 \\
\hline GML & $\begin{array}{l}\text { GPI-anchored } \\
\text { molecule-like } \\
\text { protein }\end{array}$ & $\uparrow \mathrm{HIV}$ & $\begin{array}{l}\text { Adrenal } \\
\text { gland }\end{array}$ & $\begin{array}{l}\text { Human (8) } \\
\text { Mouse (15) }\end{array}$ & GPI-anchored & $\begin{array}{l}\text { HemT-3, } \\
\text { LY6DL }\end{array}$ \\
\hline PSCA & Prostate Sca & $\uparrow \mathrm{YFV}$ & Prostate & $\begin{array}{l}\text { Human (8) } \\
\text { Mouse (15) }\end{array}$ & GPI-anchored & \\
\hline GP1HBP1 & $\begin{array}{l}\text { GPI-anchored } \\
\text { HDL-binding } \\
\text { protein } 1\end{array}$ & Unknown & $\begin{array}{l}\text { Heart, lung, } \\
\text { liver }\end{array}$ & $\begin{array}{l}\text { Human (8) } \\
\text { Mouse (15) }\end{array}$ & GPI-anchored & \\
\hline uPAR & $\begin{array}{l}\text { Urokinase } \\
\text { plasminogen } \\
\text { activator } \\
\text { surface } \\
\text { receptor }\end{array}$ & $\uparrow \mathrm{HIV}-1$ & $\begin{array}{c}\text { Monocytes, } \\
\text { dendritic } \\
\text { cells, } \\
\text { activated T } \\
\text { and NK cells, } \\
\text { endothelial } \\
\text { cells, } \\
\text { keratinocytes, } \\
\text { and } \\
\text { fibroblasts }\end{array}$ & $\begin{array}{l}\text { Human (19) } \\
\text { Mouse (7) } \\
\text { Others }\end{array}$ & GPI-anchored & $\begin{array}{l}\text { CD87, } \\
\text { PLAUR }\end{array}$ \\
\hline CD59 & $\begin{array}{l}\text { CD59 } \\
\text { molecule }\end{array}$ & $\begin{array}{c}\uparrow \text { HIV-1 } \\
\uparrow \text { HCV } \\
\text { Cytomegalovirus } \\
\uparrow \text { infectious } \\
\text { bronchitis virus } \\
\text { (IBV) }\end{array}$ & $\begin{array}{l}\text { Ubiquitously } \\
\text { expressed; } \\
\text { high in } \\
\text { erythrocyte }\end{array}$ & $\begin{array}{l}\text { Human (11) } \\
\text { Mouse (2) } \\
\text { Birds } \\
\text { Amphibians } \\
\text { Bony fishes }\end{array}$ & GPI-anchored & $\begin{array}{l}\text { 16.3A5, 1F5, } \\
\text { EJ16, } \\
\text { MAC-IP }\end{array}$ \\
\hline
\end{tabular}

Modification from reference [7,14-16]. $\uparrow$ and $\downarrow$ denote up- and down-regulation of viral infection, respectively.

There are more than 30 genes that have been classified into the LY6/uPAR superfamily [7]. The proteins encoded by the $L Y 6 / u P A R$ genes share at least one conserved functional motif, known as the LY6/uPAR (LU) domain (Figure 1a,b). The LU domain adopts a "three-fingered" folding topology characterized by $4-5$ consensus disulfide bonds and an invariant carboxyl-terminal (C-terminal) asparagine. Interestingly, the length as well as the amino acid sequences aligned at the fingertips are divergent, which renders the three-finger structure flexible for a broad range of intermolecular interactions [7]. In addition to the LU domain, Ly6/uPAR family proteins also harbor a conserved "LXCXXC" motif at the amino-terminus (N-terminus) and a "CCXXXXCN" motif at the carboxyl-terminus (C-terminus) [7] (Figure 1). The "LXCXXC" motif is thought to be the binding site for transition metal ions [18] while the function of the "CCXXXXCN" motif is less well defined.

Similar to many membrane-associated proteins, the LY6/uPAR family proteins are initially synthesized in the form of a precursor, which contains an N-terminal signal peptide (SP), an LU domain(s), and a C-terminal glycosylphosphatidylinositol (GPI) moiety anchor in most cases (Figure 1). The N-terminal SP is rapidly removed by peptidase in the endoplasmic reticulum (ER) upon translocation, while the C-terminus GPI is appended via transamidase in the ER through the conserved asparagine of the nascent protein [19]. The glycolipid GPI-anchoring requires a specific signal, which can either be a consensus motif and/or the length of amino acids following an asparagine residue $[20,21]$. Because the GPI moiety-carrying hydrophobic modification has a high affinity to 
lipid rafts, GPI-anchored proteins are often associated with lipid raft-enriched microdomains in the membrane [20]. Notably, certain LY6/uPAR proteins, such as SLURP1 (secreted Ly-6/uPAR-related protein 1) [22] and SLURP2 (secreted Ly-6/uPAR-related protein 2) [23], do not have a GPI anchor because of the lack of a GPI addition motif, and as a result, these proteins are secreted following the canonical protein secretion pathway. Noticeably, some LY6/uPAR-family proteins can form dimers or multimers via covalent or non-covalent binding [24-26], which collectively execute biological functions.

a

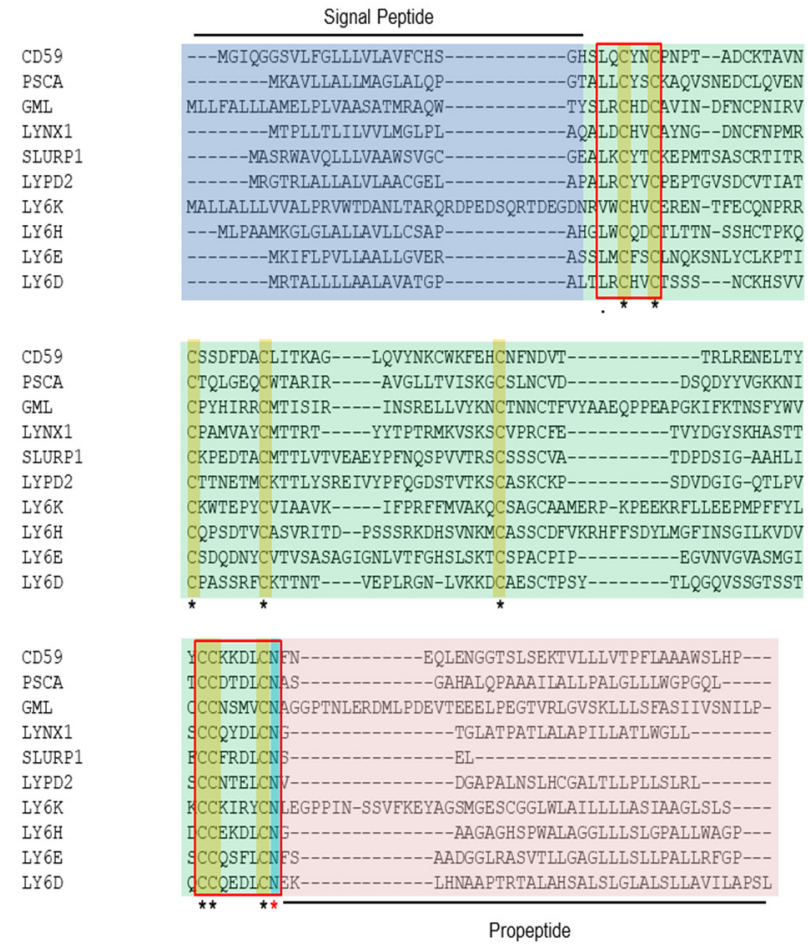

b

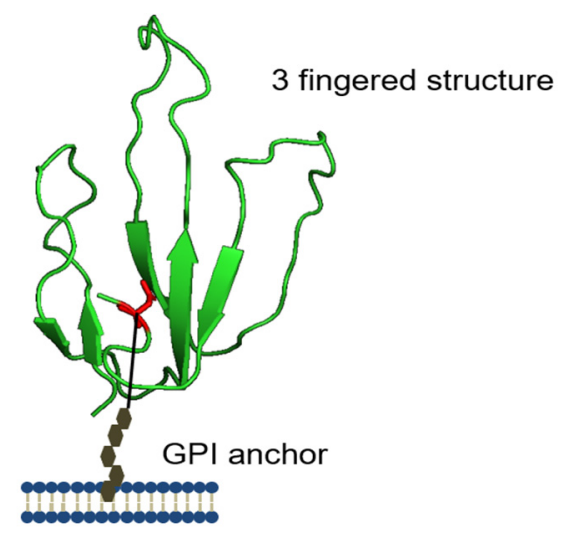

Figure 1. Sequence alignment and domain structures of LY6/uPAR family proteins. (a) Sequence alignment of major LY6/uPAR-family protein members. The shaded light blue box shows the signal peptide predicted by online software SignalP-5.0 (http://www.cbs.dtu.dk/services/SignalP/); shaded light green box shows the LU domain; and shaded light red indicates pro-peptides (GPI anchors), which are removed in mature peptides. Yellow color highlights eight conserved cysteine residues, while the cyan color shows the asparagine residue that can be glycosylated and linked to a GPI anchor. Red squares show two conserved motifs: the amino terminal "L/VXCXXC" and the carboxyl terminal "CCXXXCN". (b) Domain structure of LY6E. Human LY6E was homology-modeled based on the submitted structure of SLURP-2 (PDB ID: 2MUO). Four disulfide bonds are shown in yellow while the GPI anchor is shown in black. 
The function of Ly6/uPAR has been historically linked to immunoregulation, including $\mathrm{T}$ lymphocyte development [27], differentiation [28], activation [29], proliferation [30], and migration [16], most of which were studied in mice. Interestingly, clinical investigations of Ly6/uPAR in humans, however, have revealed some distinct pathological functions. For example, increased LY6E expression is associated with solid tumorigenesis, angiogenesis [31], systemic lupus erythematosus [32], and other abnormalities $[33,34]$. In contrast, regulation of Ly6/uPAR proteins by virus infection, and vice versa, is not well understood, and there is an emerging interest in understanding how these families of proteins influence the process of viral infection.

\section{Regulation of Ly6/uPAR Expression by Cytokines and Viral Infections}

Expression of many Ly6/uPAR-family proteins is induced by immune-regulated cytokines, including those triggered by viral infections (Table 2). For example, murine LY6A, LY6C, and LY6E are up-regulated in T lymphocytes by recombinant human interferon (IFN) $\alpha, \beta$, and $\gamma$ [35-37]. LY6C is enhanced by cytokines interleukin 27 (IL-27) and augmented by T-cell receptor (TCR) stimulation [38]. Human LY6E is characterized as a typical IFN-inducible protein or defined as an IFN-stimulated gene (ISG) [39-41]. In monocytes and monocyte-derived THP-1 cell line, LY6E is up-regulated by treatment of cells with $100 \mathrm{U} / \mathrm{mL}$ IFN $\alpha$ as early as $6 \mathrm{~h}$ [42,43]. Interestingly, another LY6 family member, SLURP-2 is enhanced by IL-22 treatment, and this effect can be completely abolished by IFN- $\gamma$ treatment [44]. The inducibility of LY6 family proteins by IFN is believed to be related to the IFN sensitive cis-acting elements within their promoter regions; however, a mechanistic study has found that the IFN $\gamma$-activating site (GAS), instead of canonical IFN $\alpha$-stimulated response element (ISRE) in the LY6 gene promoter region, is responsible for induction by IFN [45].

Given that the LY6/uPAR-family proteins can be induced by type I IFN and cellular inflammation systems, it is not surprising that viral infection, which itself triggers the type I IFN production and inflammatory response, can induce or activate the LY6/uPAR gene expression. Indeed, LY6E has been widely associated with inflammation-related abnormalities, including systemic lupus erythematosus (SLE) [32,46], solid cancer [47,48], and viral infections [49,50].

In this review, we focus on two members of the Ly/uPAR-family proteins, uPAR and CD59, in the context of their effects on viral infection. In an accompanying review of this special issue, the role of LY6E in virus-host interaction, particular viral entry, is discussed [51].

Table 2. Regulation of Ly6/uPAR expression by cytokines and viral infections ${ }^{1}$.

\begin{tabular}{|c|c|c|}
\hline Protein Name & Viral Infection & Cytokine \\
\hline LY6A & $\uparrow \mathrm{JEV}, \mathrm{WNV}$, and Reovirus [52] & $\begin{array}{c}\uparrow \text { Recombinant human IFN } \alpha, \beta \text {, } \\
\text { and } \gamma[35-37]\end{array}$ \\
\hline LY6C & $\begin{array}{l}\text { WNV infection associated with } \\
\text { lower LY6C expression [53] }\end{array}$ & $\begin{array}{l}\uparrow \text { Recombinant human IFN } \alpha, \beta \text {, } \\
\text { and } \gamma \text { [35-37] IL-27 [38] }\end{array}$ \\
\hline LY6E & $\begin{array}{c}\uparrow \text { HIV-1infection [54]; } \\
\uparrow \text { SIV [55] } \\
\uparrow \text { JEV, WNV, and Reovirus [52] }\end{array}$ & $\begin{array}{c}\uparrow \text { Recombinant human IFN } \alpha, \beta \text {, } \\
\text { and } \gamma[35-37,42,43] ; \\
\uparrow \text { Retinoic acid [41] }\end{array}$ \\
\hline LYNX1 & Unknown & $\uparrow$ IL-22 [44] \\
\hline uPAR & $\uparrow$ HIV-1gp120 in B cells [56] & $\begin{array}{c}\uparrow T N F-\alpha[57] ; \uparrow \text { IL- } 1 \beta \text { [58]; } \uparrow \text { Nerve } \\
\text { growth factor [59] }\end{array}$ \\
\hline CD59 & $\begin{array}{l}\downarrow \text { EBV [60] } \\
\downarrow \text { HBV [61] }\end{array}$ & Unknown \\
\hline
\end{tabular}

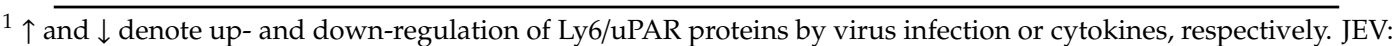
Japanese encephalitis virus; WNV: West Nile virus; HIV-1: human immunodeficiency virus type 1; SIV: Simian immunodeficiency virus; EBV: Epstein-Barr virus; HBV: hepatitis B virus.

\section{UPAR and Viral Infection}

uPAR, also known as CD87, is a heavily glycosylated, GPI-anchored cell-surface receptor [62,63]. It is predominantly expressed in immune cells, including neutrophils, monocytes/macrophages, and 
activated T cells [64]. uPAR harbors three consecutive LU repeats, namely D1, D2, and D3, respectively. The N-terminal D1 is responsible for the binding to urokinase-type plasminogen activator (uPA), the ligand of uPAR [65], and the linker peptides connect different repeats and contribute to chemotaxis [66].

Apart from the full length, several other forms of UPAR have been identified in conditioned medium from various cell lines [67], as well as in body fluids of cancer patients [68,69]. First, the intact uPAR (D1D2D3) is tethered to the cell surface by a GPI anchor attached to D3. Second, proteolytic cleavage in the linker region between D1 and D2 results in the release of the D1 fragment, leaving behind the D2D3 fragment on the cell surface. Third, soluble forms, which lack the GPI anchor but harbor either soluble uPAR (suPAR) or D2D3, can be generated by phospholipase C cleavage of the GPI anchor. In physiological settings, uPAR functions mainly through binding to its cognate ligand Urokinase-type plasminogen activator (uPA). uPA is a specific protease, which converts the plasminogen into its active form, plasmin - a broad-spectrum serine protease involved in the digestion of basement membranes and various protein substrates in the extracellular matrix [70,71]. The binding of uPA, which can be endogenously produced or released from surrounding cells, to uPAR concentrates the plasmin proteolytic activity on the relevant cell surface [72]. Therefore, the uPA/uPAR system plays a crucial role in cell migration and extravasation. Additionally, uPAR has been widely associated with vascular homeostasis, inflammation, tissue repair, cell adhesion and migration, signal transduction, tumorigenesis and metastasis, the scope of which has been elegantly reviewed elsewhere [73].

Investigation into the interplay between UPAR and viral infection can be traced back to the early 1990s, with a strong bias toward HIV studies (Table 3). It was reported that HIV-1 infection led to an enhanced cell surface expression of uPAR in monocytes and Tymphocytes in vitro and in vivo [74,75]. HIV-1 infection in tonsil histocultures significantly increased the suPAR expression in the culture medium [76]. Subsequent studies showed that uPAR mRNA was transcriptionally elevated in the context of HIV-1 infection [75]. However, how HIV-1 modulates the uPAR mRNA has remained unclear. One possibility is that HIV-1 infection may indirectly enhance uPAR expression through immune activation. It has been reported that UPAR expression is intimately regulated by some inflammation-inducing ligands, such as microbial components [77,78], mitogens [74], and pro-inflammatory cytokines $[79,80]$, and that HIV-1 infection is associated with sustained chronic immune activation and inflammation [81,82]. Interestingly, increased uPAR has also been observed in pathological conditions, such as diabetes [83], cardiovascular disorders [84], cancers [85], and live diseases [86]. However, decreased uPAR expression has also been reported in granulocytes of HIV infected patients [87], suggesting that HIV-1 infection may modulate the immune system in a cell type-specific manner.

Elevated expression of uPAR has long been associated with HIV-1 disease progression and AIDS-related deaths [88], with suPAR level in serum of untreated HIV-1 patients being significantly higher than those of healthy cohorts [88]. In addition, the suPAR level in cerebrospinal fluid (CSF) is positively correlated with the progression of HIV-1 induced central nervous system (CNS) complications [89,90]. HIV-1 positive individuals also have enhanced cell-associated uPAR in lymphoid organs, particularly in follicular dendritic cells, macrophages, and endothelial cells [76]. Higher levels of suPAR, and to a lesser extent UPA in the cerebrospinal fluid (CSF) of HIV-positive patients, were also observed compared with HIV-negative controls [90,91]. These correlative studies collectively suggest a functional interplay between HIV-1 infection and the uPA/uPAR system, strongly implicating a positive role of uPAR in HIV-1 infection.

Some in vitro and ex vivo studies have provided mechanistic insights into how uPAR might enhance HIV infection. First, uPAR synergistically functions with uPA to promote HIV infection. As a serine protease, uPA specifically cleaves peptides that harbor the consensus cleavage motif, i.e., CPGRV, which is present and conserved in the HIV envelope protein (Env) gp120 variable loop 3 region (V3) [92]. Consequently, incorporation of uPA into HIV-1 virion can lead to aberrant enzymatic processing of Env. Somewhat surprisingly, however, this cleavage facilitates CCR5-tropic HIV-1 infection of human macrophages, probably by increasing viral fusion [92]. Clinical studies revealed 
that HIV-1 pathogenesis is associated with uPAR but not uPA expression $[88,89]$, which argues against a direct role of uPA in HIV-1 infection. One possible explanation is that the plasma membrane-residing uPAR, which helps concentrate uPA on the cell surface [93], might render greater spatial proximity of the latter to the viral budding sites and thus increases the efficiency of uPA incorporation into virions and subsequent cleavage.

Second, uPAR can facilitate HIV-1 cell-to-cell spreading. It has been reported that uPA/uPAR interaction triggers signaling cascades in macrophages [93], leading to RhoA and PKC -dependent actin rearrangement [94] and subsequent intracellular enrichment of HIV-1 in a specialized structure called virus-containing compartments (VCCs) [94,95]. VCCs are regarded as invagination of the macrophage plasma membrane, which is usually connected to the extracellular space via tubular channels, and serve as the primary assembly and budding sites of HIV in macrophages [96,97]. Recently, VCC was shown to be an immune-privileged site for anti-HIV therapy [98] and antibody neutralization treatments [99]. Therefore, VCCs induced by uPA/uPAR may function as an immune privileged niche that protects HIV from a hostile environment both within and outside of the cells [97]. Additionally, VCCs can serve as HIV-1 reservoirs in macrophages and contribute to HIV-1 cell-to-cell transmission by translocating the inside virion cargoes into $\mathrm{T}$ cells through the virological synapse, a transient intercellular adhesive structure formed between infected and uninfected HIV target cells [100,101]. Given that the HIV cell-to-cell transmission is much more efficient than the cell-free infection [102], it is conceivable that uPA/uPAR signaling likely leverages the route of HIV to cell-to-cell transmission; however, details of this process warrant further investigation.

Third, uPA/uPAR can promote HIV transmission by enhancing macrophage adhesion $[103,104]$, chemotaxis [66,73], and motility [105]. It is well-known that HIV spread, in particular in vivo transmission, involves the physiological contact of macrophages with other cell types; therefore, increased adhesion and migration would allow more efficient cell-cell contact formation therefore benefit virus spread. In this sense, a friendly microenvironment, such as that created by uPA/UPAR for HIV-1 in vivo transmission, would exacerbate HIV pathogenesis.

In addition to HIV-1, increased plasma levels of uPA and UPAR have also been associated with acute and chronic hepatitis B virus infections [106]. Interestingly, in vivo studies conducted in mice showed a minor role of uPA/uPAR in limiting the virus replication and in orchestrating the innate immune response to infection by the human respiratory syncytial virus (HRSV) and influenza virus [107]. While more investigations are needed to elucidate the role of uPA and UPAR in viral infection and pathogenesis, it is possible that the effect of UPA/uPAR in the context of viral infection is virus-specific and cell type-dependent.

Table 3. Effects of LY6E and uPAR on viral infection.

\begin{tabular}{|c|c|c|c|c|c|c|}
\hline $\begin{array}{l}\text { Protein } \\
\text { Name }\end{array}$ & Virus Name & Family of Virus & $\begin{array}{l}\text { Effect on } \\
\text { Infection }\end{array}$ & $\begin{array}{l}\text { Mechanism of } \\
\text { Action }\end{array}$ & $\begin{array}{l}\text { Experimental } \\
\text { System }\end{array}$ & Reference \\
\hline \multirow[t]{3}{*}{ uPAR } & HIV-1 & Lentivirus & Enhanced & $\begin{array}{l}\text { 1. Facilitate } \\
\text { HIV-1 enzymatic } \\
\text { processing of } \\
\text { Env; } \\
\text { 2. Promote } \\
\text { HIV-1 cell-to-cell } \\
\text { transmission; } \\
\text { 3. Enhance } \\
\text { macrophage } \\
\text { adhesion. }\end{array}$ & Macrophages & $\begin{array}{c}{[92,94,95,103} \\
104]\end{array}$ \\
\hline & $\begin{array}{l}\text { Human } \\
\text { respiratory } \\
\text { syncytial } \\
\text { virus }\end{array}$ & Orthopneumovirus & Resistant & Unknown & $\begin{array}{l}\text { C57BL/6 } \\
\text { mice }\end{array}$ & [107] \\
\hline & $\begin{array}{l}\text { Influenza A } \\
\text { virus (IAV) }\end{array}$ & Orthomyxovirus & Resistant & Unknown & $\begin{array}{l}\text { C57BL/6 } \\
\text { mice }\end{array}$ & [107] \\
\hline
\end{tabular}


Table 3. Cont

\begin{tabular}{|c|c|c|c|c|c|c|}
\hline $\begin{array}{l}\text { Protein } \\
\text { Name }\end{array}$ & Virus Name & Family of Virus & $\begin{array}{l}\text { Effect on } \\
\text { Infection }\end{array}$ & $\begin{array}{l}\text { Mechanism of } \\
\text { Action }\end{array}$ & $\begin{array}{l}\text { Experimental } \\
\text { System }\end{array}$ & Reference \\
\hline \multirow{9}{*}{ CD59 } & $\mathrm{HBV}$ & Hepadnavirus & Enhanced & $\begin{array}{l}\text { 1.Promotes CDC } \\
\text { to cause } \\
\text { persistent liver } \\
\text { inflammation; } \\
\text { 2. Prevents CDC } \\
\text { in hepatoma and } \\
\text { hepatic cells that } \\
\text { express HBV-X } \\
\text { protein. }\end{array}$ & $\begin{array}{c}\text { HBV BALB/c } \\
\text { mice, } \\
\text { BEL7402, } \\
\text { HL7702, } \\
\text { HepG2 cells }\end{array}$ & {$[61,108,109]$} \\
\hline & $\begin{array}{l}\text { Human } \\
\text { cytomegalovirus } \\
\text { (HCMV) }\end{array}$ & Herpesvirus & Enhanced & $\begin{array}{l}\text { Incorporated } \\
\text { into viral } \\
\text { particles and } \\
\text { confers CDC } \\
\text { resistance. }\end{array}$ & $\begin{array}{l}\text { Human } \\
\text { Foreskin } \\
\text { Fibroblasts } \\
\text { (HFF) }\end{array}$ & [110] \\
\hline & $\begin{array}{l}\text { Varicella-zoster } \\
\text { Virus (VZV) }\end{array}$ & Herpesvirus & Enhanced & $\begin{array}{l}\text { Upregulated } \\
\text { upon VZV } \\
\text { infection to } \\
\text { protect against } \\
\text { CDC. }\end{array}$ & $\begin{array}{c}\text { Human } \\
\text { T-cells, } \\
\text { xenograft } \\
\text { SCID-hu } \\
\text { mice, } \\
\text { satellite glial } \\
\text { cells, }\end{array}$ & [111] \\
\hline & EBV & Herpesvirus & Resistant & $\begin{array}{l}\text { Decreased CD59 } \\
\text { expression to } \\
\text { allow for } \\
\text { CD8+T-cell lysis } \\
\text { via complement. }\end{array}$ & $\begin{array}{l}\text { Primary } \\
\text { T-lymphocytes } \\
\text { from acute } \\
\text { infectious } \\
\text { mononucleosis }\end{array}$ & [60] \\
\hline & $\begin{array}{l}\text { Herpesvirus } \\
\text { saimiri } \\
\text { (HVS) }\end{array}$ & Herpesvirus & Enhanced & $\begin{array}{l}\text { HVS encodes } \\
\text { CD59 mimic } \\
\text { protein to evade } \\
\text { CDC. }\end{array}$ & BALB/3T3 & {$[112,113]$} \\
\hline & $\begin{array}{c}\text { Kaposi's } \\
\text { sarcoma } \\
\text { associated } \\
\text { herpesvirus } \\
(\mathrm{KSHV})\end{array}$ & Herpesvirus & Enhanced & $\begin{array}{l}\text { Downregulation } \\
\text { by KSHV to } \\
\text { confer CDC } \\
\text { resistance. }\end{array}$ & $\begin{array}{l}\text { Human } \\
\text { umbilical } \\
\text { vein } \\
\text { endothelial } \\
\text { cells, } \\
\text { microvascular } \\
\text { endothelial } \\
\text { cells }\end{array}$ & [114] \\
\hline & $\begin{array}{l}\text { Human } \\
\text { Herpesvirus-7 } \\
\text { (HHV-7) }\end{array}$ & Herpesvirus & Enhanced & $\begin{array}{l}\text { HHV-7 infection } \\
\text { upregulates } \\
\text { CD59 to confer } \\
\text { partial CDC } \\
\text { resistance. }\end{array}$ & $\begin{array}{l}\text { SupT1, } \\
\text { PBMC }\end{array}$ & [115] \\
\hline & $\begin{array}{c}\text { Human } \\
\text { T-cell } \\
\text { lymphotropic } \\
\text { Virus Type } 1 \\
\text { (HTLV-1) }\end{array}$ & Retrovirus & Enhanced & $\begin{array}{l}\text { Incorporated } \\
\text { into viral } \\
\text { particles and } \\
\text { confers CDC } \\
\text { resistance. }\end{array}$ & MT-2 cells, & [110] \\
\hline & $\begin{array}{l}\text { Porcine } \\
\text { endogenous } \\
\text { retrovirus } \\
\text { (PERV) }\end{array}$ & Retrovirus & - & $\begin{array}{l}\text { Incorporated } \\
\text { into viral } \\
\text { particles but is } \\
\text { not sufficient for } \\
\text { CDC resistance. }\end{array}$ & $\begin{array}{c}\text { ST-IOWA } \\
\text { porcine cells }\end{array}$ & [116] \\
\hline
\end{tabular}


Table 3. Cont.

\begin{tabular}{|c|c|c|c|c|c|c|}
\hline $\begin{array}{l}\text { Protein } \\
\text { Name }\end{array}$ & Virus Name & Family of Virus & $\begin{array}{l}\text { Effect on } \\
\text { Infection }\end{array}$ & $\begin{array}{l}\text { Mechanism of } \\
\text { Action }\end{array}$ & $\begin{array}{l}\text { Experimental } \\
\text { System }\end{array}$ & Reference \\
\hline & HIV-1 & Lentivirus & Enhanced & $\begin{array}{l}\text { 1. Incorporated } \\
\text { into viral } \\
\text { particle upon } \\
\text { the budding; } \\
\text { 2. Incorporation } \\
\text { confers ADCML } \\
\text { and CDC } \\
\text { resistance; } \\
\text { 3. Decreased } \\
\text { CD59 expression } \\
\text { upon HIV-1 } \\
\text { infection in } \\
\text { CD4+ alveolar } \\
\text { macrophages; } \\
\text { 4. Co-localizes } \\
\text { with gp120/gp41 } \\
\text { within lipid } \\
\text { rafts. }\end{array}$ & $\begin{array}{c}\text { CEM, H9, U937, } \\
\text { CHO, Jurkat, } \\
\text { alveolar } \\
\text { macrophages }\end{array}$ & [117-123] \\
\hline & $\begin{array}{l}\text { Hepatitis C } \\
\text { Virus (HCV) }\end{array}$ & Flavivirus & Enhanced & $\begin{array}{c}\text { Selective } \\
\text { incorporation } \\
\text { into viral } \\
\text { particles and } \\
\text { confers ADCML } \\
\text { resistance. }\end{array}$ & Huh7.5.1 cells & {$[124,125]$} \\
\hline & \multirow[t]{2}{*}{$\begin{array}{l}\text { Dengue } \\
\text { Virus } \\
\text { (DENV) }\end{array}$} & Flavivirus & Restricted & $\begin{array}{c}\text { Decreases MAC } \\
\text { assembly to } \\
\text { reduce tissue } \\
\text { damage in } \\
\text { Dengue Fever } \\
\text { (DF) }\end{array}$ & \multirow[t]{2}{*}{ PBMC } & \multirow[t]{2}{*}[126,127]{} \\
\hline & & & Enhanced & $\begin{array}{l}\text { Monocytes are } \\
\text { more susceptible } \\
\text { to DENV } \\
\text { infection. }\end{array}$ & & \\
\hline & $\begin{array}{l}\text { Respiratory } \\
\text { Syncytial } \\
\text { Virus (RSV) }\end{array}$ & Orthopneumovirus & - & $\begin{array}{l}\text { Incorporated } \\
\text { into virus } \\
\text { filaments. }\end{array}$ & HepG2 cells & [128] \\
\hline & $\begin{array}{l}\text { Influenza A } \\
\text { virus (IAV) }\end{array}$ & Orthomyxovirus & Enhanced & $\begin{array}{l}\text { Increases lung } \\
\text { inflammation } \\
\text { and neutrophil } \\
\text { and CD4+T-cell } \\
\text { infiltration. }\end{array}$ & CD59a KO mice, & [129] \\
\hline & $\begin{array}{l}\text { Infectious } \\
\text { Bronchitis } \\
\text { Virus (IBV) }\end{array}$ & Coronavirus & Enhanced & $\begin{array}{l}\text { Associated with } \\
\text { virions and } \\
\text { downregulated } \\
\text { upon infection } \\
\text { to facilitate } \\
\text { particle release } \\
\text { and resist CDC. }\end{array}$ & $\begin{array}{l}\text { H1299, Vero, } \\
\text { DF1 cells }\end{array}$ & [130] \\
\hline & Echovirus & Picronavirus & Enhanced & $\begin{array}{c}\text { Facilitates } \\
\text { infection but not } \\
\text { virus binding. }\end{array}$ & $\begin{array}{l}\text { Rhabdomyosarcoma } \\
\text { cells }\end{array}$ & [131] \\
\hline & $\begin{array}{c}\text { Vaccinia } \\
\text { Virus (VV) }\end{array}$ & Poxvirus & Enhanced & $\begin{array}{l}\text { Incorporated } \\
\text { into viral } \\
\text { particle to evade } \\
\text { CDC. }\end{array}$ & $\begin{array}{c}\text { RK13, CV-1, } \\
\text { HeLa Aortic rat } \\
\text { endothelial cells }\end{array}$ & {$[132,133]$} \\
\hline
\end{tabular}


Table 3. Cont.

\begin{tabular}{|c|c|c|c|c|c|c|}
\hline $\begin{array}{l}\text { Protein } \\
\text { Name }\end{array}$ & Virus Name & Family of Virus & $\begin{array}{l}\text { Effect on } \\
\text { Infection }\end{array}$ & $\begin{array}{l}\text { Mechanism of } \\
\text { Action }\end{array}$ & $\begin{array}{l}\text { Experimental } \\
\text { System }\end{array}$ & Reference \\
\hline & $\begin{array}{l}\text { Parainfluenza } \\
\text { Virus } 5 \\
\text { (PIV5) }\end{array}$ & Paramyxovirus & Enhanced & $\begin{array}{l}\text { TGF-b treatment } \\
\text { increases CD59 } \\
\text { expression in } \\
\text { PIV5 progeny } \\
\text { virions } \\
\text { conferring CDC } \\
\text { resistance. }\end{array}$ & $\begin{array}{c}\text { CV-1, } \\
\text { MDBK, Vero, } \\
\text { A549, HeLa } \\
\text { cell Lines }\end{array}$ & [134] \\
\hline
\end{tabular}

"Enhanced" denotes viral infection being increased by CD59 or uPAR; "Resistant" denotes viral infection being decreased by CD59 or uPAR. "-" denotes no or minimal effects of CD59 or uPAR on viral infections. CDC—complement dependent cytolysis; ADCML—antibody dependent complement-mediated lysis.

\section{CD59 and Viral Infection}

CD59 (or protectin) is a non-interferon inducible protein initially identified as an inhibitor of complement-mediated lysis [135-137]. Preliminary sequence alignment showed limited homology with other Ly6 members; however, subsequent structural studies using PI-PLC cleavage indicated a cell surface linkage via GPI-anchor, as well as a distant evolutionary relationship with other members of the Ly6 family [135]. The most widely understood function of CD59 is its involvement in the disruption of the membrane attack complex (MAC) during complement-mediated lysis [138]. Specifically, CD59 acts in the final stages of MAC assembly by inhibiting C9 input to EC5b-8 and subsequently incorporating itself into the complex [138,139], presumably because of its similar binding pocket to the C8 $\alpha$-chain [140]. Further, this disruption is specific to complement as CD59 is not seen to disrupt perforin-mediated lysis [141]. Clinically, deficiency of CD59 is responsible for the development of paroxysmal nocturnal hemoglobinuria $(\mathrm{PNH})$, as noted by increased susceptibility of erythrocytes to complement-mediated lysis [142,143]. Interestingly, cells from patients with PNH can re-acquire resistance to hemolysis when incubated with CD59 [144,145]. The involvement of CD59 in complement lysis and subsequently its dysregulation in PNH has been extensively characterized and reviewed by [146].

CD59 is expressed on a wide variety of cell types [147], and in accordance, has numerous non-complement-dependent roles. CD59 is accumulated in tumor cells [148], and there has been directly targeted and down-modulated by using monoclonal antibodies (mAbs), shRNA and other small molecules for therapeutics [149,150]. CD59 is also implicated in T-cell signaling [149,151] and regulates cell growth and apoptosis. For example, CD59 can coordinately interact with CD2 during T-cell activation and adhesion [152,153]. In CD3+ Jurkat cells, activation of ZAP-70 and p65lck results in activation of the T-cell receptor and downstream signaling to produce interleukin 2 (IL-2) [154]. This interaction is mediated via a mobile Lck fraction [155] and an adaptor protein linker for activation of T-cells (LAT) that is recruited to lipid rafts [147,151-157], which is the characteristic localization region for members of Ly6/uPAR proteins.

There is a growing body of literature showing the involvement of CD59 in viral infection and pathogenesis. CD59 has been shown to interact with numerous viruses, either directly or indirectly, through complement-dependent and independent mechanisms. Generally, these interactions can be classified into three categories: (1) Incorporation of CD59 into viral envelopes to evade complement virolysis; (2) modulation of CD59 on the cell surface to escape immune sensing; and (3) expression of virus-encoded CD59-mimic proteins.

By far the most characterized virus-CD59 interactions are with HIV-1/2 and related SIVs. Several reports have shown a decreased surface expression of CD59 on peripheral blood T-lymphocytes [122], erythrocytes [158], neuronal and astroglial cells [159] in HIV-1 patients. In the latter study, cells treated with recombinant gp41 showed a decreased CD59 level. While no direct evidence for increased complement-mediated damage was observed, the likely outcome of this down-modulation of CD59 is increased complement-mediated lysis. Indeed, when these cells were treated with phorbol dibutyrate ( $\mathrm{PdBu}$; an activator of protein kinase C-PKC), CD59 levels were decreased following treatment with 
recombinant gp41, suggesting a PKC-dependent signaling role. Similar results have been observed when pro-inflammatory cytokines (IL-1 $\beta$, IFN- $\gamma$ ) and LPS are used in neuronal cell lines. Interestingly, subsequent experiments to identify complement activation in H9 cells by HIV-1 and HIV-2 isolates found no difference in CD59 levels [160]. However, when HIV particles were analyzed using virus capture assay, complement-inhibiting protein decay-accelerating factor (DAF) was found to be incorporated into viral particles, with CD59 also incorporated but to a lesser extent, which would lead to protection from complement-mediated lysis $[118,120]$. Similar complement-controlling proteins are seen in SIV particles, which likely helps infected cells escape from complement-mediated killing [119]. The incorporation of complement control proteins in HIV particles is not restricted to CD59, as both DAF (also known as CD55) and CD45 are incorporated into viral particles [121]. It should be noted that although early reports suggested that HIV-1 is insensitive to complement lysis, whether or not the incorporation of CD59 and other complement controlling proteins are sufficient to allow for this escape remains to be determined.

Incorporation of cellular proteins into virions and subsequent immune evasion has been reported for numerous host proteins. For example, CD59 is incorporated into viral particles of vaccinia virus [132], human T-cell leukemia/lymphoma virus (HTLV-1), human cytomegalovirus (HCMV) [110,161], infectious bronchitis virus (IBV) [130], hepatitis C virus [124], Newcastle disease virus [162], as well as parainfluenza virus 5 [134] among others (Table 3). In IBV-infected cells, the cell surface level of CD59 is down-regulated because of incorporation into viral particles. IBV production from CD59 knock-down cells was significantly reduced; along the same lines, when the GPI-anchor of CD59 is cleaved by using PI-PLC, the titer of IBV was also significantly reduced [130]. HCV particles purified from cell culture showed CD59 incorporation in the viral membranes [124], which is co-localized with HCV proteins during the assembly process [125]. Similar GPI-dependence has been observed in production of HIV-1 particles, where GPI-anchor deficiency rendered viruses more susceptible to complement-mediated lysis [117].

Intriguingly, herpesvirus saimiri (HVS) encodes a gene ORF15 with $64 \%$ nucleotide homology to CD59 [112]. Structural characterization showed that the HVS CD59 protein shares the single N-linked glycosylation with human CD59 and the highly conserved cysteine residues [41]. The N-linked glycosylation site is predicted to be responsible for the cross-species specific complement-resistance activity [113]. For example, human CD59 and saimiri CD59 are not cross-protective against rat complement, and HVS CD59 provides no protection against human or rat serum. This is likely attributed to the differentially located glycosylation site of HVSCD59 as compared to the conserved primate CD59 glycosylation sites [113]. While further studies are required to determine the exact mechanism of protection, or lack thereof, the viral mimicry of complement control proteins has been observed in numerous other viruses [163].

Antagonism of host-cellular proteins is a hallmark for productive infection in viruses. Downregulation of CD59 from the surface of virus-infected cells is a common cellular mechanism hijacked by viral particles to promote complement-mediated lysis either for viral egress or chronic disease manifestation. For instance, CD59 is significantly reduced in monocytes from DENV-infected patients [127]. Similar results have been seen in patients with chronic HBV infection. Using HBV transgenic mice expressing HBV genome, Qu et al. showed decreased levels of CD59 at both mRNA and protein levels [61]. Similar observations were seen in hepatocytes infected with HBV and this downregulation was specific to CD59, as neither CD55 nor crry (another complement controlling protein) were significantly changed upon infection. It is now known that the HBV core protein, which is responsible for this downregulation, sensitizes hepatocytes, thus resulting in lysis and subsequent liver damage [109]. HepG2 cells transfected with HBV core protein selectively form complexes with CD59 and they are recapitulated in liver samples from HBV patients. Interestingly, these complexes are seen to translocate to the nucleus, resulting in decreased surface expression and an overall increase in susceptibility to MAC [109]. 
The modulation of CD59 levels on the cell surface has also been employed by other viruses. For instance, varicella-zoster virus upregulates CD59 in thymus/liver and dorsal root ganglia (DRG) xenografts in-vivo. Interestingly, this upregulation is tissue or cell-specific, as similar infections in skin xenografts showed only modest upregulation [111]. The exact mechanism of this upregulation remains unclear. CD59 upregulation is thought to be a consequence of upstream NF-kB activation; however, VZV is known to inhibit NF-kB signaling in skin implants. Interestingly, antibodies against CD59 block infection to a range of echoviruses in RD cells. Noteworthy is that echovirus 7 uses DAF as a receptor for entry and that blocking CD59 does not affect the virus binding to DAF or cell-to-cell spread. It is hypothesized that CD59 acts at an early stage of virus entry but not during the attachment.

CD59 is involved in diverse and essential cellular functions, especially in its protection of "self" from complement-mediated lysis. Thus, it is not surprising that viruses have evolved strategies to exploit this function, either through incorporation of it into viral envelopes or by mimicking the functional capacity of CD59. CD59 also appears to be an attractive target for therapeutic strategies to prevent or control viral pathogenesis. Indeed, recent therapeutic efforts have focused on inhibiting CD59 by using hCD59 inhibitors [164], or antibodies combined with anti-HIV Env antibody or serum from HIV-1 infected individuals [165]. However, the challenge is that CD59 molecule is widely distributed on the cell surface and performs some important cellular functions. Therefore, strategies to specifically target CD59 on the virion membrane should be pursued.

\section{Concluding Remarks and Future Perspectives}

Some general conclusions can be drawn from the research performed on UPAR and CD59 proteins related to viral infections. First, Ly6/uPAR proteins can function through direct and indirect mechanisms. Second, Ly6/uPAR molecules influence viral infection in a cell context-dependent and virus-specific fashion. Last, the function of Ly6/uPAR is related to the GPI-anchored topology of these proteins, as well as their lipid-raft localizations.

Notably, most Ly6/uPAR-family members remain uncharacterized in the context of viral infection. This is especially important, given that some of these proteins may have a redundant, cooperative, or synergistic effect in viral infection. For example, knockdown of one Ly6/uPAR member may affect-either inhibit or enhance - the functions of others during viral replication. While GPI anchor is known to affect the protein location and interactions with others, how exactly the Ly6/uPAR proteins with a GPI anchor regulate cell signaling, migration, and other physiological processes involved in viral infection remain largely unknown. Hence, it would be interesting and informative to use global and comparative approaches to examine the effects of LY6/uPAR family members in the context of innate and adaptive immune response to viral infection. Finally, most of the published studies have been derived from in vitro or mouse experiments, roles of Ly6/uPAR in human viral infections need to be determined, including under pathological conditions. Additionally, genetic mapping and single nucleotide polymorphism (SNP) studies of human Ly6/uPAR genes will provide insights into the role of Ly6/uPAR-family members in viral infection and virus-host co-evolution.

Author Contributions: J.Y., V.M. and S.-L.L. conceptualized the idea of the review; J.Y. and V.M. wrote the manuscript; S.-L.L. proofread and edited the review.

Funding: This research was funded by NIH grants R01 AI112381 and NIH R01 AI150473 awarded to S.-L.L.

Acknowledgments: We thank members of the Liu lab, past and present, for helpful discussion.

Conflicts of Interest: The authors declare no conflict of interest.

\section{References}

1. Woody, J.N. Ly-6 is a T-cell differentiation antigen. Nature 1977, 269, 61-63. [CrossRef] [PubMed]

2. McKenzie, I.F.; Gardiner, J.; Cherry, M.; Snell, G.D. Lymphocyte antigens: Ly-4, Ly-6, and Ly-7. Transplant. Proc. 1977, 9, 667-669. [PubMed] 
3. LeClair, K.P.; Palfree, R.G.; Flood, P.M.; Hammerling, U.; Bothwell, A. Isolation of a murine Ly-6 cDNA reveals a new multigene family. EMBO J. 1986, 5, 3227-3234. [CrossRef] [PubMed]

4. Palfree, R.G.; LeClair, K.P.; Bothwell, A.; Hammerling, U. cDNA characterization of an Ly-6.2 gene expressed in BW5147 tumor cells. Immunogenetics 1987, 26, 389-391. [CrossRef]

5. Classon, B.J.; Coverdale, L. Mouse stem cell antigen Sca-2 is a member of the Ly-6 family of cell surface proteins. Proc. Natl. Acad. Sci. USA 1994, 91, 5296-5300. [CrossRef]

6. Pflugh, D.L.; Maher, S.E.; Bothwell, A.L. Ly-6I, a new member of the murine Ly-6 superfamily with a distinct pattern of expression. J. Immunol. 2000, 165, 313-321. [CrossRef]

7. Loughner, C.L.; Bruford, E.A.; McAndrews, M.S.; Delp, E.E.; Swamynathan, S.; Swamynathan, S.K. Organization, evolution and functions of the human and mouse Ly6/uPAR family genes. Hum. Genom. 2016, 10, 10. [CrossRef]

8. Koh, K.; Joiner, W.J.; Wu, M.N.; Yue, Z.; Smith, C.J.; Sehgal, A. Identification of SLEEPLESS, a sleep-promoting factor. Science 2008, 321, 372-376. [CrossRef]

9. Herberg, S.; Gert, K.R.; Schleiffer, A.; Pauli, A. The Ly6/uPAR protein Bouncer is necessary and sufficient for species-specific fertilization. Science 2018, 361, 1029-1033. [CrossRef]

10. Da Silva, S.M.; Gates, P.B.; Brockes, J.P. The newt ortholog of CD59 is implicated in proximodistal identity during amphibian limb regeneration. Dev. Cell 2002, 3, 547-555. [CrossRef]

11. Fry, B.G.; Wuster, W.; Kini, R.M.; Brusic, V.; Khan, A.; Venkataraman, D.; Rooney, A.P. Molecular evolution and phylogeny of elapid snake venom three-finger toxins. J. Mol. Evol. 2003, 57, 110-129. [CrossRef] [PubMed]

12. Liu, H.C.; Niikura, M.; Fulton, J.E.; Cheng, H.H. Identification of chicken lymphocyte antigen 6 complex, locus E (LY6E, alias SCA2) as a putative Marek's disease resistance gene via a virus-host protein interaction screen. Cytogenet. Genome Res. 2003, 102, 304-308. [CrossRef] [PubMed]

13. Holmes, R.S.; Cox, L.A. Comparative studies of glycosylphosphatidylinositol-anchored high-density lipoprotein-binding protein 1: Evidence for a eutherian mammalian origin for the GPIHBP1 gene from an LY6-like gene. 3 Biotech 2012, 2, 37-52. [CrossRef] [PubMed]

14. Gumley, T.P.; McKenzie, I.F.; Sandrin, M.S. Tissue expression, structure and function of the murine Ly-6 family of molecules. Immunol. Cell Biol. 1995, 73, 277-296. [CrossRef] [PubMed]

15. Bamezai, A. Mouse Ly-6 proteins and their extended family: Markers of cell differentiation and regulators of cell signaling. Arch. Immunol. Therap. Exp. 2004, 52, 255-266.

16. Lee, P.Y.; Wang, J.-X.; Parisini, E.; Dascher, C.C.; Nigrovic, P.A. Ly6 family proteins in neutrophil biology. J. Leukocyte Biol. 2013, 94, 585-594. [CrossRef] [PubMed]

17. Loeuillet, C.; Deutsch, S.; Ciuffi, A.; Robyr, D.; Taffe, P.; Munoz, M.; Beckmann, J.S.; Antonarakis, S.E.; Telenti, A. In vitro whole-genome analysis identifies a susceptibility locus for HIV-1. PLoS Biol. 2008, 6, e32. [CrossRef] [PubMed]

18. Sahlman, L.; Skarfstad, E.G. Mercuric ion binding abilities of MerP variants containing only one cysteine. Biochem. Biophys. Res. Commun. 1993, 196, 583-588. [CrossRef]

19. Orlean, P.; Menon, A.K. Thematic review series: Lipid posttranslational modifications. GPI anchoring of protein in yeast and mammalian cells, or: How we learned to stop worrying and love glycophospholipids. J. Lipid Res. 2007, 48, 993-1011. [CrossRef]

20. Eisenhaber, B.; Maurer-Stroh, S.; Novatchkova, M.; Schneider, G.; Eisenhaber, F. Enzymes and auxiliary factors for GPI lipid anchor biosynthesis and post-translational transfer to proteins. BioEssays News Rev. Mol. Cell. Dev. Biol. 2003, 25, 367-385. [CrossRef]

21. Su, B.; Bothwell, A.L. Biosynthesis of a phosphatidylinositol-glycan-linked membrane protein: Signals for posttranslational processing of the Ly-6E antigen. Mol. Cell. Biol. 1989, 9, 3369-3376. [CrossRef] [PubMed]

22. Favre, B.; Plantard, L.; Aeschbach, L.; Brakch, N.; Christen-Zaech, S.; de Viragh, P.A.; Sergeant, A.; Huber, M.; Hohl, D. SLURP1 Is a Late Marker of Epidermal Differentiation and Is Absent in Mal de Meleda. J. Investig. Dermatol. 2007, 127, 301-308. [CrossRef]

23. Arredondo, J.; Chernyavsky, A.I.; Jolkovsky, D.L.; Webber, R.J.; Grando, S.A. SLURP-2: A novel cholinergic signaling peptide in human mucocutaneous epithelium. J. Cell. Physiol. 2006, 208, 238-245. [CrossRef] 
24. Plengpanich, W.; Young, S.G.; Khovidhunkit, W.; Bensadoun, A.; Karnman, H.; Ploug, M.; Gardsvoll, H.; Leung, C.S.; Adeyo, O.; Larsson, M.; et al. Multimerization of glycosylphosphatidylinositol-anchored high density lipoprotein-binding protein 1 (GPIHBP1) and familial chylomicronemia from a serine-to-cysteine substitution in GPIHBP1 Ly6 domain. J. Biol. Chem. 2014, 289, 19491-19499. [CrossRef] [PubMed]

25. Pawlak, J.; Mackessy, S.P.; Sixberry, N.M.; Stura, E.A.; Le Du, M.H.; Menez, R.; Foo, C.S.; Menez, A.; Nirthanan, S.; Kini, R.M. Irditoxin, a novel covalently linked heterodimeric three-finger toxin with high taxon-specific neurotoxicity. FASEB J. 2009, 23, 534-545. [CrossRef] [PubMed]

26. Cunningham, O.; Andolfo, A.; Santovito, M.L.; Iuzzolino, L.; Blasi, F.; Sidenius, N. Dimerization controls the lipid raft partitioning of uPAR/CD87 and regulates its biological functions. EMBO J. 2003, 22, 5994-6003. [CrossRef]

27. MacNeil, I.; Kennedy, J.; Godfrey, D.I.; Jenkins, N.A.; Masciantonio, M.; Mineo, C.; Gilbert, D.J.; Copeland, N.G.; Boyd, R.L.; Zlotnik, A. Isolation of a cDNA encoding thymic shared antigen-1. A new member of the Ly6 family with a possible role in T cell development. J. Immunol. 1993, 151, 6913-6923.

28. Mallya, M.; Campbell, R.D.; Aguado, B. Characterization of the five novel Ly-6 superfamily members encoded in the MHC, and detection of cells expressing their potential ligands. Prot. Sci. 2006, 15, 2244-2256. [CrossRef]

29. Van de Rijn, M.; Heimfeld, S.; Spangrude, G.J.; Weissman, I.L. Mouse hematopoietic stem-cell antigen Sca-1 is a member of the Ly-6 antigen family. Proc. Natl. Acad. Sci. USA 1989, 86, 4634-4638. [CrossRef]

30. Stanford, W.L.; Haque, S.; Alexander, R.; Liu, X.; Latour, A.M.; Snodgrass, H.R.; Koller, B.H.; Flood, P.M. Altered Proliferative Response by T Lymphocytes of Ly-6A (Sca-1) Null Mice. J. Exp. Med. 1997, 186, 705-717. [CrossRef]

31. Yeom, C.J.; Zeng, L.; Goto, Y.; Morinibu, A.; Zhu, Y.; Shinomiya, K.; Kobayashi, M.; Itasaka, S.; Yoshimura, M.; Hur, C.G.; et al. LY6E: A conductor of malignant tumor growth through modulation of the PTEN/PI3K/Akt/HIF-1 axis. Oncotarget 2016, 7, 65837-65848. [CrossRef] [PubMed]

32. Han, G.M.; Chen, S.L.; Shen, N.; Ye, S.; Bao, C.D.; Gu, Y.Y. Analysis of gene expression profiles in human systemic lupus erythematosus using oligonucleotide microarray. Genes Immun. 2003, 4, 177-186. [CrossRef] [PubMed]

33. Kruse, J.J.; te Poele, J.A.; Velds, A.; Kerkhoven, R.M.; Boersma, L.J.; Russell, N.S.; Stewart, F.A. Identification of differentially expressed genes in mouse kidney after irradiation using microarray analysis. Radiat. Res. 2004, 161, 28-38. [CrossRef] [PubMed]

34. Sommer, C.A.; Pavarino-Bertelli, E.C.; Goloni-Bertollo, E.M.; Henrique-Silva, F. Identification of dysregulated genes in lymphocytes from children with Down syndrome. Genome 2008, 51, 19-29. [CrossRef] [PubMed]

35. Dumont, F.J. Recombinant human interferon-alpha A/D enhances the expression of Ly-6A/E, Ly-6C, and TAP antigens on murine T lymphocytes. J. Interferon Res. 1988, 8, 347-356. [CrossRef]

36. Dumont, F.J.; Coker, L.Z. Interferon- $\alpha / \beta$ enhances the expression of Ly- 6 antigens on T cells in vivo and in vitro. Eur. J. Immunol. 1986, 16, 735-740. [CrossRef]

37. Dumont, F.J.; Dijkmans, R.; Palfree, R.G.E.; Boltz, R.D.; Coker, L. Selective up-regulation by interferon- $\gamma$ of surface molecules of the Ly- 6 complex in resting T cells: The Ly-6A/E and TAP antigens are preferentially enhanced. Eur. J. Immunol. 1987, 17, 1183-1191. [CrossRef]

38. DeLong, J.H.; Hall, A.O.H.; Muallem, G.; Hunter, C.A. Ly6C expression on T cells is modulated by IL-27, interferon-gamma and TCR stimulation. J. Immunol. 2016, 196 (Suppl. 1), 196.9.

39. Lu, J.; Pan, Q.; Rong, L.; He, W.; Liu, S.L.; Liang, C. The IFITM proteins inhibit HIV-1 infection. J. Virol. 2011, 85, 2126-2137. [CrossRef]

40. Schoggins, J.W.; Wilson, S.J.; Panis, M.; Murphy, M.Y.; Jones, C.T.; Bieniasz, P.; Rice, C.M. A diverse range of gene products are effectors of the type I interferon antiviral response. Nature 2011, 472, 481-485. [CrossRef]

41. Mao, M.; Yu, M.; Tong, J.H.; Ye, J.; Zhu, J.; Huang, Q.H.; Fu, G.; Yu, L.; Zhao, S.Y.; Waxman, S.; et al. RIG-E, a human homolog of the murine Ly-6 family, is induced by retinoic acid during the differentiation of acute promyelocytic leukemia cell. Proc. Natl. Acad. Sci. USA 1996, 93, 5910-5914. [CrossRef] [PubMed]

42. Mar, K.B.; Rinkenberger, N.R.; Boys, I.N.; Eitson, J.L.; McDougal, M.B.; Richardson, R.B.; Schoggins, J.W. LY6E mediates an evolutionarily conserved enhancement of virus infection by targeting a late entry step. Nat. Commun. 2018, 9, 3603. [CrossRef] [PubMed] 
43. Xu, X.; Qiu, C.; Zhu, L.; Huang, J.; Li, L.; Fu, W.; Zhang, L.; Wei, J.; Wang, Y.; Geng, Y.; et al. IFN-stimulated gene LY6E in monocytes regulates the CD14/TLR4 pathway but inadequately restrains the hyperactivation of monocytes during chronic HIV-1 infection. J. Immunol. 2014, 193, 4125-4136. [CrossRef] [PubMed]

44. Moriwaki, Y.; Takada, K.; Tsuji, S.; Kawashima, K.; Misawa, H. Transcriptional regulation of SLURP2, a psoriasis-associated gene, is under control of IL-22 in the skin: A special reference to the nested gene LYNX1. Int. Immunopharmacol. 2015, 29, 71-75. [CrossRef]

45. Khan, K.D.; Shuai, K.; Lindwall, G.; Maher, S.E.; Darnell, J.E.; Bothwell, A.L. Induction of the Ly-6A/E gene by interferon alpha/beta and gamma requires a DNA element to which a tyrosine-phosphorylated 91-kDa protein binds. Proc. Natl. Acad. Sci. USA 1993, 90, 6806-6810. [CrossRef]

46. Wahadat, M.J.; Bodewes, I.L.A.; Maria, N.I.; van Helden-Meeuwsen, C.G.; van Dijk-Hummelman, A.; Steenwijk, E.C.; Kamphuis, S.; Versnel, M.A. Type I IFN signature in childhood-onset systemic lupus erythematosus: A conspiracy of DNA- and RNA-sensing receptors? Arthritis Res. Ther. 2018, $20,4$. [CrossRef]

47. Gou, S.; Liu, T.; Wang, C.; Yin, T.; Li, K.; Yang, M.; Zhou, J. Establishment of clonal colony-forming assay for propagation of pancreatic cancer cells with stem cell properties. Pancreas 2007, 34, 429-435. [CrossRef]

48. Luo, L.; McGarvey, P.; Madhavan, S.; Kumar, R.; Gusev, Y.; Upadhyay, G. Distinct lymphocyte antigens 6 (Ly6) family members Ly6D, Ly6E, Ly6K and Ly6H drive tumorigenesis and clinical outcome. Oncotarget 2016, 7, 11165-11193. [CrossRef]

49. Zhang, W.; Li, H.; Cheng, G.; Hu, S.; Li, Z.; Bi, D. Avian influenza virus infection induces differential expression of genes in chicken kidney. Res. Vet. Sci. 2008, 84, 374-381. [CrossRef]

50. Spindler, K.R.; Welton, A.R.; Lim, E.S.; Duvvuru, S.; Althaus, I.W.; Imperiale, J.E.; Daoud, A.I.; Chesler, E.J. The major locus for mouse adenovirus susceptibility maps to genes of the hematopoietic cell surface-expressed LY6 family. J. Immunol. 2010, 184, 3055-3062. [CrossRef]

51. Yu, J.; Liu, S.L. Emerging Role of LY6E in Virus-Host Interactions. Viruses 2019, 11, 1020. [CrossRef] [PubMed]

52. Clarke, P.; Leser, J.S.; Bowen, R.A.; Tyler, K.L. Virus-induced transcriptional changes in the brain include the differential expression of genes associated with interferon, apoptosis, interleukin 17 receptor $\mathrm{A}$, and glutamate signaling as well as flavivirus-specific upregulation of tRNA synthetases. mBio 2014, 5, e00902-e00914. [CrossRef] [PubMed]

53. Terry, R.L.; Deffrasnes, C.; Getts, D.R.; Minten, C.; van Vreden, C.; Ashhurst, T.M.; Getts, M.T.; Xie, R.D.; Campbell, I.L.; King, N.J. Defective inflammatory monocyte development in IRF8-deficient mice abrogates migration to the West Nile virus-infected brain. J. Innate Immun. 2015, 7, 102-112. [CrossRef] [PubMed]

54. Yu, J.; Liang, C.; Liu, S.L. Interferon-inducible LY6E Protein Promotes HIV-1 Infection. J. Biol. Chem. 2017, 292, 4674-4685. [CrossRef] [PubMed]

55. Lu, W.; Ma, F.; Churbanov, A.; Wan, Y.; Li, Y.; Kang, G.; Yuan, Z.; Wang, D.; Zhang, C.; Xu, J.; et al. Virus-host mucosal interactions during early SIV rectal transmission. Virology 2014, 464-465, 406-414. [CrossRef]

56. Jelicic, K.; Cimbro, R.; Nawaz, F.; Huang, D.W.; Zheng, X.; Yang, J.; Lempicki, R.A.; Pascuccio, M.; Van Ryk, D.; Schwing, C.; et al. The HIV-1 envelope protein gp120 impairs B cell proliferation by inducing TGF-beta1 production and FcRL4 expression. Nat. Immunol. 2013, 14, 1256-1265. [CrossRef]

57. Lund, L.R.; Romer, J.; Ronne, E.; Ellis, V.; Blasi, F.; Dano, K. Urokinase-receptor biosynthesis, mRNA level and gene transcription are increased by transforming growth factor beta 1 in human A549 lung carcinoma cells. EMBO J. 1991, 10, 3399-3407. [CrossRef]

58. Hasegawa, T.; Sorensen, L.; Dohi, M.; Rao, N.V.; Hoidal, J.R.; Marshall, B.C. Induction of urokinase-type plasminogen activator receptor by IL-1 beta. Am. J. Respir. Cell Mol. Biol. 1997, 16, 683-692. [CrossRef]

59. Farias-Eisner, R.; Vician, L.; Silver, A.; Reddy, S.; Rabbani, S.A.; Herschman, H.R. The urokinase plasminogen activator receptor (UPAR) is preferentially induced by nerve growth factor in PC12 pheochromocytoma cells and is required for NGF-driven differentiation. J. Neurosci. 2000, 20, 230-239. [CrossRef]

60. Kawano, M.; Tsunoda, S.; Koni, I.; Mabuchi, H.; Muramoto, H.; Yachie, A.; Seki, H. Decreased expression of 20-kD homologous restriction factor (HRF20, CD59) on T lymphocytes in Epstein-Barr virus (EBV)-induced infectious mononucleosis. Clin. Exp. Immunol. 1997, 108, 260-265. [CrossRef]

61. Qu, Z.; Liang, X.; Liu, Y.; Du, J.; Liu, S.; Sun, W. Hepatitis B virus sensitizes hepatocytes to complement-dependent cytotoxicity through downregulating CD59. Mol. Immunol. 2009, 47, 283-289. [CrossRef] [PubMed] 
62. Ploug, M.; Rahbek-Nielsen, H.; Nielsen, P.F.; Roepstorff, P.; Dano, K. Glycosylation profile of a recombinant urokinase-type plasminogen activator receptor expressed in Chinese hamster ovary cells. J. Biol. Chem. 1998, 273, 13933-13943. [CrossRef] [PubMed]

63. Behrendt, N.; Ronne, E.; Ploug, M.; Petri, T.; Lober, D.; Nielsen, L.S.; Schleuning, W.D.; Blasi, F.; Appella, E.; Dano, K. The human receptor for urokinase plasminogen activator. NH2-terminal amino acid sequence and glycosylation variants. J. Biol. Chem. 1990, 265, 6453-6460. [PubMed]

64. Plesner, T.; Behrendt, N.; Ploug, M. Structure, function and expression on blood and bone marrow cells of the urokinase-type plasminogen activator receptor, uPAR. Stem Cells 1997, 15, 398-408. [CrossRef] [PubMed]

65. Gardsvoll, H.; Dano, K.; Ploug, M. Mapping part of the functional epitope for ligand binding on the receptor for urokinase-type plasminogen activator by site-directed mutagenesis. J. Biol. Chem. 1999, 274, 37995-38003. [CrossRef]

66. Fazioli, F.; Resnati, M.; Sidenius, N.; Higashimoto, Y.; Appella, E.; Blasi, F. A urokinase-sensitive region of the human urokinase receptor is responsible for its chemotactic activity. EMBO J. 1997, 16, 7279-7286. [CrossRef]

67. Lau, H.K.F.; Kim, M. Soluble Urokinase Receptor from Fibrosarcoma Ht-1080 Cells. Blood Coagul. Fibrin. 1994, 5, 473-478.

68. Sier, C.F.M.; Stephens, R.; Bizik, J.; Mariani, A.; Bassan, M.; Pedersen, N.; Frigerio, L.; Ferrari, A.; Dano, K.; Brunner, N.; et al. The level of urokinase-type plasminogen activator receptor is increased in serum of ovarian cancer patients. Cancer Res. 1998, 58, 1843-1849.

69. Wahlberg, K.; Hoyer-Hansen, G.; Casslen, B. Soluble receptor for urokinase plasminogen activator in both full-length and a cleaved form is present in high concentration in cystic fluid from ovarian cancer. Cancer Res. 1998, 58, 3294-3298.

70. Kobayashi, H.; Schmitt, M.; Goretzki, L.; Chucholowski, N.; Calvete, J.; Kramer, M.; Gunzler, W.A.; Janicke, F.; Graeff, H. Cathepsin B efficiently activates the soluble and the tumor cell receptor-bound form of the proenzyme urokinase-type plasminogen activator (Pro-uPA). J. Biol. Chem. 1991, 266, 5147-5152.

71. Vassalli, J.D.; Sappino, A.P.; Belin, D. The plasminogen activator/plasmin system. J. Clin. Investig. 1991, 88, 1067-1072. [CrossRef] [PubMed]

72. Collen, D. The plasminogen (fibrinolytic) system. Thrombosis Haemostasis 1999, 82, 259-270. [CrossRef] [PubMed]

73. Blasi, F.; Carmeliet, P. uPAR: A versatile signalling orchestrator. Nat. Rev. Mol. Cell Bio. 2002, 3, 932-943. [CrossRef] [PubMed]

74. Nykjaer, A.; Moller, B.; Todd, R.F.; Christensen, T.; Andreasen, P.A.; Gliemann, J.; Petersen, C.M. Urokinase Receptor-An Activation Antigen in Human T-Lymphocytes. J. Immunol. 1994, 152, 505-516. [PubMed]

75. Speth, C.; Pichler, I.; Stocki, G.; Mir, M.; Dierich, M.P. Urokinase plasminogen activator receptor (uPAR.; CD87) expression on monocytic cells and T cells is modulated by HIV-1 infection. Immunobiology 1998, 199, 152-162. [CrossRef]

76. Nebuloni, M.; Zawada, L.; Ferri, A.; Tosoni, A.; Zerbi, P.; Resnati, M.; Poli, G.; Genovese, L.; Alfano, M. HIV-1 Infected Lymphoid Organs Upregulate Expression and Release of the Cleaved Form of uPAR That Modulates Chemotaxis and Virus Expression. PLoS ONE 2013, 8, e70606. [CrossRef]

77. Coleman, J.L.; Gebbia, J.A.; Benach, J.L. Borrelia burgdorferi and other bacterial products induce expression and release of the urokinase receptor (CD87). J. Immunol. 2001, 166, 473-480. [CrossRef]

78. Todd, R.F.; Alvarez, P.A.; Brott, D.A.; Liu, D.Y. Bacterial Lipopolysaccharide, Phorbol-Myristate Acetate, and Muramyl Dipeptide Stimulate the Expression of a Human Monocyte Surface-Antigen, Mo3e. J. Immunol. 1985, 135, 3869-3877.

79. Kirchheimer, J.C.; Nong, Y.H.; Remold, H.G. Ifn-Gamma, Tumor Necrosis Factor-Alpha, and Urokinase Regulate the Expression of Urokinase Receptors on Human-Monocytes. J. Immunol. 1988, 141, 4229-4234.

80. Sitrin, R.G.; Todd, R.F., 3rd; Mizukami, I.F.; Gross, T.J.; Shollenberger, S.B.; Gyetko, M.R. Cytokine-specific regulation of urokinase receptor (CD87) expression by U937 mononuclear phagocytes. Blood 1994, 84, 1268-1275.

81. Appay, V.; Sauce, D. Immune activation and inflammation in HIV-1 infection: Causes and consequences. J. Pathol. 2008, 214, 231-241. [CrossRef] [PubMed]

82. Brenchley, J.M.; Price, D.A.; Schacker, T.W.; Asher, T.E.; Silvestri, G.; Rao, S.; Kazzaz, Z.; Bornstein, E.; Lambotte, O.; Altmann, D.; et al. Microbial translocation is a cause of systemic immune activation in chronic HIV infection. Nat. Med. 2006, 12, 1365-1371. [CrossRef] [PubMed] 
83. Haugaard, S.B.; Andersen, O.; Hansen, T.W.; Eugen-Olsen, J.; Linneberg, A.; Madsbad, S.; Olsen, M.H.; Jorgensen, T.; Borch-Johnsen, K.; Jeppesen, J. The immune marker soluble urokinase plasminogen activator receptor is associated with new-onset diabetes in non-smoking women and men. Diabetic Med. 2012, 29, 479-487. [CrossRef] [PubMed]

84. Manetti, M.; Allanore, Y.; Revillod, L.; Fatini, C.; Guiducci, S.; Cuomo, G.; Bonino, C.; Riccieri, V.; Bazzichi, L.; Liakouli, V.; et al. A Genetic Variation Located in the Promoter Region of the UPAR (CD87) Gene Is Associated With the Vascular Complications of Systemic Sclerosis. Arthritis Rheum. 2011, 63, 247-256. [CrossRef] [PubMed]

85. Mazar, A.P.; Henkin, J.; Goldfarb, R.H. The urokinase plasminogen activator system in cancer: Implications for tumor angiogenesis and metastasis. Angiogenesis 1999, 3, 15-32. [CrossRef]

86. Giamarellos-Bourboulis, E.J.; Norrby-Teglund, A.; Mylona, V.; Savva, A.; Tsangaris, I.; Dimopoulou, I.; Mouktaroudi, M.; Raftogiannis, M.; Georgitsi, M.; Linner, A.; et al. Risk assessment in sepsis: A new prognostication rule by APACHE II score and serum soluble urokinase plasminogen activator receptor. Crit. Care 2012, 16, R149. [CrossRef]

87. Storgaard, M.; Obel, N.; Black, F.T.; Moller, B.K. Decreased urokinase receptor expression on granulocytes in HIV-infected patients. Scand. J. Immunol. 2002, 55, 409-413. [CrossRef]

88. Sidenius, N.; Sier, C.F.M.; Ullum, H.; Pedersen, B.K.; Lepri, A.C.; Blasi, F.; Eugen-Olsen, J. Serum level of soluble urokinase-type plasminogen activator receptor is a strong and independent predictor of survival in human immunodeficiency virus infection. Blood 2000, 96, 4091-4095.

89. Sporer, B.; Koedel, U.; Popp, B.; Paul, R.; Pfister, H.W. Evaluation of cerebrospinal fluid uPA, PAI-1, and soluble uPAR levels in HIV-infected patients. J. Neuroimmunol. 2005, 163, 190-194. [CrossRef]

90. Cinque, P.; Nebuloni, M.; Santovito, M.L.; Price, R.W.; Gisslen, M.; Hagberg, L.; Bestetti, A.; Vago, G.; Lazzarin, A.; Blasi, F.; et al. The urokinase receptor is overexpressed in the AIDS dementia complex and other neurological manifestations. Ann. Neurol. 2004, 55, 687-694. [CrossRef]

91. Sidenius, N.; Nebuloni, M.; Sala, S.; Zerbi, P.; Price, R.W.; Gisslen, M.; Hagberg, L.; Vago, L.; Lazzarin, A.; Blasi, F.; et al. Expression of the urokinase plasminogen activator and its receptor in HIV-1-associated central nervous system disease. J. Neuroimmunol. 2004, 157, 133-139. [CrossRef] [PubMed]

92. Handley, M.A.; Steigbigel, R.T.; Morrison, S.A. A role for urokinase-type plasminogen activator in human immunodeficiency virus type 1 infection of macrophages. J. Virol. 1996, 70, 4451-4456. [PubMed]

93. Blasi, F.; Sidenius, N. The urokinase receptor: Focused cell surface proteolysis, cell adhesion and signaling. FEBS Lett. 2010, 584, 1923-1930. [CrossRef] [PubMed]

94. Graziano, F.; Elia, C.; Laudanna, C.; Poli, G.; Alfano, M. Urokinase plasminogen activator inhibits HIV virion release from macrophage-differentiated chronically infected cells via activation of RhoA and PKCepsilon. PLoS ONE 2011, 6, e23674. [CrossRef] [PubMed]

95. Alfano, M.; Sidenius, N.; Panzeri, B.; Blasi, F.; Poli, G. Urokinase-urokinase receptor interaction mediates an inhibitory signal for HIV-1 replication. Proc. Natl. Acad. Sci. USA 2002, 99, 8862-8867. [CrossRef] [PubMed]

96. Pelchen-Matthews, A.; Kramer, B.; Marsh, M. Infectious HIV-1 assembles in late endosomes in primary macrophages. J. Cell Biol. 2003, 162, 443-455. [CrossRef]

97. Tan, J.; Sattentau, Q.J. The HIV-1-containing macrophage compartment: A perfect cellular niche? Trends Microbiol. 2013, 21, 405-412. [CrossRef]

98. Aquaro, S.; Perno, C.F. Assessing the relative efficacy of antiretroviral activity of different drugs on macrophages. Methods Mol. Biol. 2005, 304, 445-453.

99. Koppensteiner, H.; Banning, C.; Schneider, C.; Hohenberg, H.; Schindler, M. Macrophage internal HIV-1 is protected from neutralizing antibodies. J. Virol. 2012, 86, 2826-2836. [CrossRef]

100. Groot, F.; Welsch, S.; Sattentau, Q.J. Efficient HIV-1 transmission from macrophages to T cells across transient virological synapses. Blood 2008, 111, 4660-4663. [CrossRef]

101. Jolly, C.; Kashefi, K.; Hollinshead, M.; Sattentau, Q.J. HIV-1 cell to cell transfer across an Env-induced, actin-dependent synapse. J. Exp. Med. 2004, 199, 283-293. [CrossRef] [PubMed]

102. Sattentau, Q. Avoiding the void: Cell-to-cell spread of human viruses. Nat. Rev. Microbiol. 2008, 6, 815-826. [CrossRef] [PubMed]

103. Chapman, H.A. Plasminogen activators, integrins, and the coordinated regulation of cell adhesion and migration. Curr Opin Cell Biol 1997, 9, 714-724. [CrossRef] 
104. Ossowski, L.; Aguirre-Ghiso, J.A. Urokinase receptor and integrin partnership: Coordination of signaling for cell adhesion, migration and growth. Curr. Opin. Cell Biol. 2000, 12, 613-620. [CrossRef]

105. Smith, H.W.; Marshall, C.J. Regulation of cell signalling by uPAR. Nat. Rev. Mol. Cell Bio. 2010, 11, $23-36$. [CrossRef]

106. Zhou, H.; Wu, X.; Lu, X.; Chen, G.; Ye, X.; Huang, J. Evaluation of plasma urokinase-type plasminogen activator and urokinase-type plasminogen-activator receptor in patients with acute and chronic hepatitis $\mathrm{B}$. Thrombosis Res. 2009, 123, 537-542. [CrossRef]

107. Ramos, M.; Lao, Y.; Eguiluz, C.; Del Val, M.; Martinez, I. Urokinase receptor-deficient mice mount an innate immune response to and clarify respiratory viruses as efficiently as wild-type mice. Virulence 2015, 6, 710-715. [CrossRef]

108. Shan, C.; Zhang, S.; Cui, W.; You, X.; Kong, G.; Du, Y.; Qiu, L.; Ye, L.; Zhang, X. Hepatitis B virus X protein activates CD59 involving DNA binding and let-7i in protection of hepatoma and hepatic cells from complement attack. Carcinogenesis 2011, 32, 1190-1197. [CrossRef]

109. Liu, D.; Ni, B.; Wang, L.; Zhang, M.; Liu, W.; Wu, Y. Hepatitis B virus core protein interacts with CD59 to promote complement-mediated liver inflammation during chronic hepatitis B virus infection. FEBS Lett. 2013, 587, 3314-3320. [CrossRef]

110. Spear, G.T.; Lurain, N.S.; Parker, C.J.; Ghassemi, M.; Payne, G.H.; Saifuddin, M. Host cell-derived complement control proteins CD55 and CD59 are incorporated into the virions of two unrelated enveloped viruses. Human T cell leukemia/lymphoma virus type I (HTLV-I) and human cytomegalovirus (HCMV). J. Immunol. 1995, 155, 4376-4381.

111. Wang, W.; Wang, X.; Yang, L.; Fu, W.; Pan, D.; Liu, J.; Ye, J.; Zhao, Q.; Zhu, H.; Cheng, T.; et al. Modulation of host CD59 expression by varicella-zoster virus in human xenografts in vivo. Virology 2016, 491, 96-105. [CrossRef] [PubMed]

112. Albrecht, J.C.; Nicholas, J.; Cameron, K.R.; Newman, C.; Fleckenstein, B.; Honess, R.W. Herpesvirus saimiri has a gene specifying a homologue of the cellular membrane glycoprotein CD59. Virology 1992, 190, 527-530. [CrossRef]

113. Rother, R.P.; Rollins, S.A.; Fodor, W.L.; Albrecht, J.C.; Setter, E.; Fleckenstein, B.; Squinto, S.P. Inhibition of complement-mediated cytolysis by the terminal complement inhibitor of herpesvirus saimiri. J. Virol. 1994, 68, 730-737. [PubMed]

114. Lee, M.S.; Jones, T.; Song, D.Y.; Jang, J.H.; Jung, J.U.; Gao, S.J. Exploitation of the complement system by oncogenic Kaposi's sarcoma-associated herpesvirus for cell survival and persistent infection. PLoS Pathog. 2014, 10, e1004412. [CrossRef]

115. Takemoto, M.; Yamanishi, K.; Mori, Y. Human herpesvirus 7 infection increases the expression levels of CD46 and CD59 in target cells. J. Gen. Virol. 2007, 88 Pt 5, 1415-1422. [CrossRef]

116. Takefman, D.M.; Spear, G.T.; Saifuddin, M.; Wilson, C.A. Human CD59 incorporation into porcine endogenous retrovirus particles: Implications for the use of transgenic pigs for xenotransplantation. J. Virol. 2002, 76, 1999-2002. [CrossRef]

117. Amet, T.; Lan, J.; Shepherd, N.; Yang, K.; Byrd, D.; Xing, Y.; Yu, Q. Glycosylphosphatidylinositol Anchor Deficiency Attenuates the Production of Infectious HIV-1 and Renders Virions Sensitive to Complement Attack. AIDS Res. Hum. Retroviruses 2016, 32, 1100-1112. [CrossRef]

118. Marschang, P.; Sodroski, J.; Würzner, R.; Dierich, M.P. Decay-accelerating factor (CD55) protects human immunodeficiency virus type 1 from inactivation by human complement. Eur. J. Immunol. 1995, 25, 285-290. [CrossRef]

119. Montefiori, D.C.; Cornell, R.J.; Zhou, J.Y.; Zhou, J.T.; Hirsch, V.M.; Johnson, P.R. Complement Control Proteins, CD46, CD55, and CD59, as Common Surface Constituents of Human and Simian Immunodeficiency Viruses and Possible Targets for Vaccine Protection. Virology 1994, 205, 82-92. [CrossRef]

120. Saifuddin, M.; Ghassemi, M.; Patki, C.; Parker, C.J.; Spear, G.T. Host cell components affect the sensitivity of HIV type 1 to complement-mediated virolysis. AIDS Res. Hum. Retroviruses 1994, 10, 829-837. [CrossRef]

121. Saifuddin, M.; Hedayati, T.; Atkinson, J.P.; Holguin, M.H.; Parker, C.J.; Spear, G.T. Human immunodeficiency virus type 1 incorporates both glycosyl phosphatidylinositol-anchored CD55 and CD59 and integral membrane CD46 at levels that protect from complement-mediated destruction. J. Gen. Virol. 1997, 78, 1907-1911. [CrossRef] [PubMed] 
122. Weiss, L.; Okada, N.; Haeffner-Cavaillon, N.; Hattori, T.; Faucher, C.; Kazatchkine, M.D.; Okada, H. Decreased expression of the membrane inhibitor of complement-mediated cytolysis CD59 on T-lymphocytes of HIV-infected patients. AIDS 1992, 6, 379-385. [CrossRef] [PubMed]

123. Aries, S.P.; Schaaf, B.; Hansen, F.; Weyrich, K.; Kurowski, V.; Dennin, R.; Dalhoff, K. Expression of complement receptors and regulatory proteins on alveolar CD4+ lymphocytes from human immunodeficiency virus-1 infected individuals. Eur. Respir. J. 1997, 10, 1736-1741. [CrossRef] [PubMed]

124. Amet, T.; Ghabril, M.; Chalasani, N.; Byrd, D.; Hu, N.; Grantham, A.; Liu, Z.; Qin, X.; He, J.J.; Yu, Q. CD59 incorporation protects hepatitis $C$ virus against complement-mediated destruction. Hepatology 2012, 55, 354-363. [CrossRef] [PubMed]

125. Ejaz, A.; Steinmann, E.; Bánki, Z.; Anggakusuma; Khalid, S.; Lengauer, S.; Wilhelm, C.; Zoller, H.; Schloegl, A.; Steinmann, J.; et al. Specific Acquisition of Functional CD59 but Not CD46 or CD55 by Hepatitis C Virus. PLoS ONE 2012, 7, e45770. [CrossRef] [PubMed]

126. Ubol, S.; Masrinoul, P.; Chaijaruwanich, J.; Kalayanarooj, S.; Charoensirisuthikul, T.; Kasisith, J. Differences in global gene expression in peripheral blood mononuclear cells indicate a significant role of the innate responses in progression of dengue fever but not dengue hemorrhagic fever. J. Infect. Dis. 2008, 197, 1459-1467. [CrossRef] [PubMed]

127. Marinho, C.F.; Azeredo, E.L.; Torrentes-Carvalho, A.; Marins-Dos-Santos, A.; Kubelka, C.F.; de Souza, L.J.; Cunha, R.V.; de-Oliveira-Pinto, L.M. Down-Regulation of Complement Receptors on the Surface of Host Monocyte Even as In Vitro Complement Pathway Blocking Interferes in Dengue Infection. PLoS ONE 2014, 9, e102014. [CrossRef]

128. Brown, G.; Jeffree, C.E.; McDonald, T.; Rixon, H.W.; Aitken, J.D.; Sugrue, R.J. Analysis of the interaction between respiratory syncytial virus and lipid-rafts in Hep2 cells during infection. Virology 2004, 327, 175-185. [CrossRef]

129. Longhi, M.P.; Williams, A.; Wise, M.; Morgan, B.P.; Gallimore, A. CD59a deficiency exacerbates influenza-induced lung inflammation through complement-dependent and-independent mechanisms. Eur. J. Immunol. 2007, 37, 1266-1274. [CrossRef]

130. Wei, Y.; Ji, Y.; Guo, H.; Zhi, X.; Han, S.; Zhang, Y.; Gao, Y.; Chang, Y.; Yan, D.; Li, K.; et al. CD59 association with infectious bronchitis virus particles protects against antibody-dependent complement-mediated lysis. $J$. Gen. Virol. 2017, 98, 2725-2730. [CrossRef]

131. Goodfellow, I.G.; Powell, R.M.; Ward, T.; Spiller, O.B.; Almond, J.W.; Evans, D.J. Echovirus infection of rhabdomyosarcoma cells is inhibited by antiserum to the complement control protein CD59. J. Gen. Virol. 2000, 81, 1393-1401. [CrossRef] [PubMed]

132. Vanderplasschen, A.; Mathew, E.; Hollinshead, M.; Sim, R.B.; Smith, G.L. Extracellular enveloped vaccinia virus is resistant to complement because of incorporation of host complement control proteins into its envelope. Proc. Natl. Acad. Sci. USA 1998, 95, 7544-7549. [CrossRef] [PubMed]

133. Krauss, O.; Hollinshead, R.; Hollinshead, M.; Smith, G.L. An investigation of incorporation of cellular antigens into vaccinia virus particles. J. Gen. Virol. 2002, 83, 2347-2359. [CrossRef] [PubMed]

134. Li, Y.; Parks, G.D. Relative Contribution of Cellular Complement Inhibitors CD59, CD46, and CD55 to Parainfluenza Virus 5 Inhibition of Complement-Mediated Neutralization. Viruses 2018, 10, 219. [CrossRef] [PubMed]

135. Davies, A.; Simmons, D.L.; Hale, G.; Harrison, R.A.; Tighe, H.; Lachmann, P.J.; Waldmann, H. CD59, an LY-6-like protein expressed in human lymphoid cells, regulates the action of the complement membrane attack complex on homologous cells. J. Exp. Med. 1989, 170, 637-654. [CrossRef]

136. Holguin, M.H.; Wilcox, L.A.; Bernshaw, N.J.; Rosse, W.F.; Parker, C.J. Relationship between the membrane inhibitor of reactive lysis and the erythrocyte phenotypes of paroxysmal nocturnal hemoglobinuria. J. Clin. Invest. 1989, 84, 1387-1394. [CrossRef]

137. Sugita, Y.; Mazda, T.; Tomita, M. Amino-terminal amino acid sequence and chemical and functional properties of a membrane attack complex-inhibitory factor from human erythrocyte membranes. J. Biochem. 1989, 106, 589-592. [CrossRef]

138. Meri, S.; Morgan, B.P.; Davies, A.; Daniels, R.H.; Olavesen, M.G.; Waldmann, H.; Lachmann, P.J. Human protectin (CD59), an 18,000-20,000 MW complement lysis restricting factor, inhibits C5b-8 catalysed insertion of C9 into lipid bilayers. Immunology 1990, 71, 1-9. 
139. Rollins, S.A.; Sims, P.J. The complement-inhibitory activity of CD59 resides in its capacity to block incorporation of C9 into membrane C5b-9. J. Immunol. 1990, 144, 3478-3483.

140. Chang, C.P.; Hüsler, T.; Zhao, J.; Wiedmer, T.; Sims, P.J. Identity of a peptide domain of human C9 that is bound by the cell-surface complement inhibitor, CD59. J. Biol. Chem. 1994, 269, 26424-26430.

141. Meri, S.; Morgan, B.P.; Wing, M.; Jones, J.; Davies, A.; Podack, E.; Lachmann, P.J. Human protectin (CD59), an 18-20-kD homologous complement restriction factor, does not restrict perforin-mediated lysis. J. Exp. Med. 1990, 172, 367-370. [CrossRef] [PubMed]

142. Yamashina, M.; Ueda, E.; Kinoshita, T.; Takami, T.; Ojima, A.; Ono, H.; Tanaka, H.; Kondo, N.; Orii, T.; Okada, N.; et al. Inherited Complete Deficiency of 20-Kilodalton Homologous Restriction Factor (CD59) as a Cause of Paroxysmal Nocturnal Hemoglobinuria. N. Engl. J. Med. 1990, 323, 1184-1189. [CrossRef] [PubMed]

143. Zalman, L.S.; Wood, L.; Frank, M.; Mueller-Eberhard, H.J. Deficiency of the homologous restriction factor in paroxysmal nocturnal hemoglobinuria. J. Exp. Med. 1987, 165, 572-577. [CrossRef] [PubMed]

144. Okada, N.; Harada, R.; Taguchi, R.; Okada, H. Complete deficiency of 20 KDa homologous restriction factor (HRF20) and restoration with purified HRF20. Biochem. Biophys. Res. Commun. 1989, 164, 468-473. [CrossRef]

145. Okada, N.; Harada, R.; Okada, H. Erythrocytes of patients with paroxysmal nocturnal haemoglobinuria acquire resistance to complement attack by purified 20-kD homologous restriction factor. Clin. Exp. Immunol. 1990, 80, 109-113. [CrossRef]

146. Wyrick-Glatzel, J.; MacDonald, J.K.; Chen, J.-J. Paroxysmal Nocturnal Hemoglobinemia: A Molecular Definition of the Clinical Biology of the Disorder. Lab. Med. 2006, 37, 237-243. [CrossRef]

147. Walsh, L.A.; Tone, M.; Thiru, S.; Waldmann, H. The CD59 antigen-A multifunctional molecule. Tissue Antigens 1992, 40, 213-220. [CrossRef]

148. Yan, J.; Allendorf, D.J.; Li, B.; Yan, R.; Hansen, R.; Donev, R. The Role of Membrane Complement Regulatory Proteins in Cancer Immunotherapy. In Current Topics in Complement II; Lambris, J.D., Ed.; Springer: New York, NY, USA, 2008; pp. 152-167.

149. Kimberley, F.C.; Sivasankar, B.; Paul Morgan, B. Alternative roles for CD59. Mol. Immunol. 2007, 44, 73-81. [CrossRef]

150. Zhang, R.; Liu, Q.; Liao, Q.; Zhao, Y. CD59: A promising target for tumor immunotherapy. Fut. Oncol. 2018, 14, 781-791. [CrossRef]

151. Korty, P.E.; Brando, C.; Shevach, E.M. CD59 functions as a signal-transducing molecule for human T cell activation. J. Immunol. 1991, 146, 4092-4098.

152. Deckert, M.; Kubar, J.; Zoccola, D.; Bernard-Pomier, G.; Angelisova, P.; Horejsi, V.; Bernard, A. CD59 molecule: A second ligand for CD2 in T cell adhesion. Eur. J. Immunol. 1992, 22, 2943-2947. [CrossRef] [PubMed]

153. Deckert, M.; Ticchioni, M.; Mari, B.; Mary, D.; Bernard, A. The glycosylphosphatidylinositol-anchored CD59 protein stimulates both $\mathrm{T}$ cell receptor $\zeta / \mathrm{ZAP}-70-d e p e n d e n t$ and -independent signaling pathways in $\mathrm{T}$ cells. Eur. J. Immunol. 1995, 25, 1815-1822. [CrossRef] [PubMed]

154. Deckert, M.; Kubar, J.; Bernard, A. CD58 and CD59 molecules exhibit potentializing effects in T cell adhesion and activation. J. Immunol. 1992, 148, 672-677. [PubMed]

155. Lipp, A.M.; Juhasz, K.; Paar, C.; Ogris, C.; Eckerstorfer, P.; Thuenauer, R.; Hesse, J.; Nimmervoll, B.; Stockinger, H.; Schütz, G.J.; et al. Lck Mediates Signal Transmission from CD59 to the TCR/CD3 Pathway in Jurkat T Cells. PLoS ONE 2014, 9, e85934. [CrossRef] [PubMed]

156. Wang, L.-N.; Gao, M.-H.; Wang, B.; Cong, B.-B.; Zhang, S.-C. A role for GPI-CD59 in promoting T-cell signal transduction via LAT. Oncol. Lett. 2018, 15, 4873-4881. [CrossRef] [PubMed]

157. Longhi, M.P.; Harris, C.L.; Morgan, B.P.; Gallimore, A. Holding T cells in check - a new role for complement regulators? Trends Immunol. 2006, 27, 102-108. [CrossRef]

158. Terpos, E.; Sarantopoulos, A.; Kouramba, A.; Katsarou, O.; Stavropoulos, J.; Masouridi, S.; Karafoulidou, A.; Meletis, J. Reduction of CD55 and/or CD59 in red blood cells of patients with HIV infection. Med. Sci. Monit. 2008, 14, CR276-CR280.

159. Chong, Y.; Lee, M.J. Expression of complement inhibitor protein CD59 in human neuronal and glial cell lines treated with HIV-1 gp41 peptides. J. Neurovirol. 2000, 6, 51-60. [CrossRef]

160. Marschang, P.; Gurtler, L.; Totsch, M.; Thielenst, N.M.; Arlaudt, G.J.; Hittmair, A.; Katingers, H.; Dierich, M.P. HIV-I and HIV-2 isolates differ in their ability to activate the complement system on the surface of infected cells. AIDS 1993, 7, 903. [CrossRef] 
161. Spiller, O.B.; Hanna, S.M.; Devine, D.V.; Tufaro, F. Neutralization of cytomegalovirus virions: The role of complement. J. Infect. Dis. 1997, 176, 339-347. [CrossRef]

162. Rangaswamy, U.S.; Cotter, C.R.; Cheng, X.; Jin, H.; Chen, Z. CD55 is a key complement regulatory protein that counteracts complement-mediated inactivation of Newcastle Disease Virus. J. Gen. Virol. 2016, 97, 1765-1770. [CrossRef] [PubMed]

163. Bernet, J.; Mullick, J.; Singh, A.K.; Sahu, A. Viral mimicry of the complement system. J. Biosci. 2003, 28, 249-264. [CrossRef] [PubMed]

164. Hu, W.; Yu, Q.; Hu, N.; Byrd, D.; Amet, T.; Shikuma, C.; Shiramizu, B.; Halperin, J.A.; Qin, X. A High-Affinity Inhibitor of Human CD59 Enhances Complement-Mediated Virolysis of HIV-1: Implications for Treatment of HIV-1/AIDS. J. Immunol. 2010, 184, 359-368. [CrossRef] [PubMed]

165. Lan, J.; Yang, K.; Byrd, D.; Hu, N.; Amet, T.; Shepherd, N.; Desai, M.; Gao, J.; Gupta, S.; Sun, Y.; et al. Provirus activation plus CD59 blockage triggers antibody-dependent complement-mediated lysis of latently HIV-1-infected cells. J. Immunol. 2014, 193, 3577-3589. [CrossRef] [PubMed]

(C) 2019 by the authors. Licensee MDPI, Basel, Switzerland. This article is an open access article distributed under the terms and conditions of the Creative Commons Attribution (CC BY) license (http://creativecommons.org/licenses/by/4.0/). 